\title{
NBSIR 75.682
}

\section{Basic Considerations of Densitometer Adjustment and Calibration}

Richard E. Swing

Institute for Basic Standards National Bureau of Standards

Washington, D. C. 20234

February 3, 1975

Interim Report

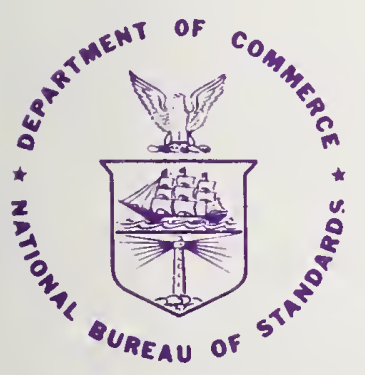

U. S. DEPARTMENT OF COMMERCE

NATIONAL BUREAU OF STANDARDS 

NBSIR 75-682

\section{BASIC CONSIDERATIONS OF DENSITOMETER}

\section{ADJUSTMENT AND CALIBRATION}

Richard E. Swing

Institute for Basic Standards

National Bureau of Standards

Washington, D. C. 20234

February 3, 1975

Interim Report 

This document has been prepared as part of the program to upgrade and improve the density-measurement capability at NBS through research in the Optics and Micrometrology Section of the Optical Physics Division. It is the first of several that will be released in this subject-area, and will occasionally undergo revision and expansion as the program develops. At the end of the program, a complete NBS report on Densitometry and related matters w11l be prepared and published. 
The considerations of this note are linted to instruments which measure large-area, or macro-density (as opposed to microdensity) and to those devices in which the geometry of 1llumination and 11ghtcollection are permanently fixed within the system. Further, we shall restrict our discussion to transmission density (although many of the principles of adjustment and calibration will apply to reflection density measurement), and limit the type of density measured to that known as diffuse (or singly diffuse).

\section{STANDARDS}

There are two types of standards that must be considered. Documentary standards are written procedures or methods which define the quantities to be measured, specify the conditions under which measurements will be valid and useful, and provide guidance in the interpretation of results. Physical measurement standards provide a means for transferring measurements of the same quantity from a "standard" instrument to an "operational" instrument. The physical measurement standard is used to provide an absolute measurement of a quantity that is repeatable, conforms to an accepted documentary standard and whose prectsion of measurement is certifiable. The physical measurement standard is then used to bring an instrument's response into conformity with another's. This guarantees that the Instrument output is identical (in the mathematical sense), or related, to that which was in effect when the physical measurement standard was calibrated. Thus, the instrument response is such that when measurements are subsequently made on other materials, the results are said to be "traceable" to the calibrating source, and in principle, can be reproduced on the source's measurement instrument.

In the case of transmission density, the documentary standard is ANSI Standard PH2.19-1959, "American Standard Diffuse Transmission Density," and the physical measurement standard is a step tablet calibrated at the National Bureau of Standards.

\section{NBS TRANSMISSION DENSITY PHYSICAI STANDARDS}

Diffuse density and its measurement are governed by the cited ANSI documentary standard. This standard is currently under revision by ANSI Subcomittee PH2.28. The two techniques used at NBS for calibration of physical measurement standards for optical density are in full conformance with the provisions of the documentary standard. Primary density standard calibrations are achieved through an inversesquare technique. This method provides density measurements with a certifiable precision of 0.005 density units or 1/2-percent, whichever 
1s larger. The calibration of a secondary, less-preclse physical measurement standard is accomplished with a densitometer that itself has been calibrated with a NBS primary density standard, and used with a geometry and procedure equivalent to those specifled for ANSI measurements of diffuse density. This method provides density measurements with a certiflable precision of 0.01 density undts or 1percent, whichever is larger. All densteles measured at NBS are characterlzed as diffuse (visual) demsity, a spectral type of diffuse density that relates to the average notmal human eye adapted to photopic vision.

NBS routinely provides caltbrated step tablets (21 steps, on a 3.5 x $25 \mathrm{~cm}$ tablet) through the offlce of Standard Reference Materials. SRM-1009 has a density range of 0 to 3.0, whyle SRM-1008 increases the upper limit to 4.0. The precision in both cases is 0.01 density units or 1 percent, whichever ls larger. These sablets are also sultable for primary standards, but nust be calibrated on the inverse-square instrument to the cited precision. Prlary standards are only provided on request, because the need 18 less and because they are more than ten times as costly as the secondary atandarda.

Occasionally, NBS will calibrate user-bubmitted step tablets. However, when these are solled, scratched, flogerprinted or otherwise blemished, or contain non-uniform demsities whthin the varlous steps NBS will return them uncalibrated. NBS prefers to provide the basic tablet for calibration. Thls results from an important concern of diffuse density measurement. When the denstromster $1 \mathrm{~s}$ configured in conformance with ANSI Standard PH2.19-1959, denstry so measured is independent of the materlal comprising the step tablet. Scattering or other density-varying attributes of materlals do not enter into this measurement. However, denstrometers that do nor conform to the standard configuration will glve varying responses with different materials, and NBS strongly suggests that lasirumers be brought into conformity to eliminate this difficulty。

\section{PRACTICAL DENSITOMETER ADJUSTMENT}

The purpose of the calibrated step tablets, consistent with the role of physical measurement standards, is the calibration of normal operational instrument response in rerms of diffuse (visual) density. This is necessary for several reasons.

Each densitometer, no matter the manufacturer, design, configuration or mode of operation, obtalns an indication of illuminance in the aperture of his detector system that results from the passage of light through the sample. The mode of indication varies. In some instruments, it is a meter-needle read against a scale; in others it may be digltized. Mherever it is, the 
manufacturer, to provide means whereby the instrument can be reset to obtain reproducible results, supplies an adjustment procedure.

Th1s adjustment procedure commonly adjusts the needle reading (or other output indication) at a density value of zero and at one other density value much higher on the scale. Having done this, it is not uncommon to check a third point, although it is not necessary. It is only necessary to be able to reproduce this adjustment, at the two values, whenever it is required.

At this instrument setting, the densitometer has a response determined by the photometric measurement system. It may be linear, it may not be. In a meter-needle/density scale system the system response 18 assumed to follow the scale markings; when they are equally-spaced, the response is assumed to be linear. The logarithmic amplifiers in the device are usually of high quality, and the output is generally linear over a reasonable range. But stralght-line response from the origin to densities in excess of 3.0 depends on having a logarithmic converter that reads accurately over an input voltage range of $1000: 1$. This is difficult to do without correcting adjustments. It is particularly true of instruments fabricated on a production basis. The dial (or other readout device) and electronic clrcuits are designed and installed according to nominal speciflcations, but like the "average man," are not expected to exist as exactly specifled for all instruments, for all time. But perfect straight-line response is not really necessary; vartability can be compensated by the simple procedure of callbration.

\section{PRACTICAL DENSITOMETER CALIBRATION}

Calibration of the instrument against a physical measurement standard modifies the assumed (or indicated) response so that the instrument produces correct values of diffuse density. Calibration is effected by first adfusting the densitometer according to the procedure discussed previously. After adjustment, the physical measurement standard is then inserted into the measuring system and each step read and recorded.* Th1s gives a set of values of Instrument reading corresponding to the set of diffuse density values on the standard. The calibration is summarized in the form of a plotted curve of Instrument Reading vs. Diffuse Density, or in a Calibration Table (discussed in the next Section). If the instrument

*As with all such measurements, these are repeated as often as necessary to establish a good statistical base, so that the user has sufficient confidence in the results to subject them to subsequent analysis and use. 
conforms to ANSI standard geometry and 1llumination, and the step tablet used to calibrate it has values of diffuse density (measured in the manner directed by the documentary standard), then all readings subsequently made with the instrument are characterized as diffuse density (using the calibration curve or table), within the precision of the step tablet used for the callbration and the measurement tolerances of the instrument data readout.

Thus, in principle, the need for bullding the "perfect" or "nearperfect" densitometer does not exist. Any reasonable response can be compensated through calibration. Practically, it is convenient not to have to use a curve or table to correct instrument readings; the saving in time alone is often sufficient to repay the added cost for accuracy in density measurement. But even the best instruments require calibration: it checks system response, determines error bounds, and provides a "traceab1l1ty" In the measurement procedure.

Calibration of densitometers is particularly essential in instruments that are not strictly configured to measure diffuse density. A prime example of this is the microdensitometer which measures a specular density that varies with the numerical apertures of the opt1cs. Macrodensitometers that do not meet ANSI specifications for diffuse density must also undergo thorough and repeated callbration to reduce readings to diffuse density values. The frequency of calibration and the precision of the standard used depend to a great extent on the purpose of the instrument. In many instances, comercial interests do not require calibration curves or tablets, but merely insist that the instrument read to within some specified density range for each step on the calibration tablet. A typical value is t0.05 density units. When a periodic check agalnst the physical measurement standard indicates departure of density values beyond these error bounds, the instrument is serviced. For inspection, acceptance-testing or sorting operations, the application of such error bounds is adequate. However, for precision use (where subsequent calculations w1ll be based on the characteristic curve of the material, for example) calibration curves or tables are a necessity.

\section{CALIBRATION DISPLAY AND USE}

Calibration displays should reflect the precision of measurement, be accurately drawn or summarlzed and be convenient to use. Ordinarily, most densitometers can read to 0.02 density units (scale divisions); some can visually interpolate to 0.01 density units quite accurately. Most digital displays have a least-count of 0.01 . Thus, If the operator is going to read density to the nearest 0.01 unit, his calibration display should reflect that precision. If he chooses to 
plot his calibration, he should not be required to interpolate between lines to obtain his corrections. This stems from the problem of eye fatigue and loss of time in tracking between lines from the abscissa up to the curve - then over to the ordinate value. For densities on the physical standard up to, say 4.0, 400 separate and distinct Iines on his graph paper are required, in both dimensions. For nearly all cases, this requires a sheet of paper that is prohibitively large, although by halving (and using the spaces between IInes, with its attendant interpolation problem), the paper size can sometimes be reduced to manageability. Accuracy will be affected by the ability to use a draftsman's spline (French Curve) In connecting the points to make a smooth curve. Unless a great deal of care is exercised, the precision inherent both in the calibration and the physical measurement standard will disappear, and the precision implied by the abscissa and ordinate graduations will be 11 lusory.

Probably the most accurate way of displaying callbration information 18 in a Calibration Table. Thls is a listing of Instrument Reading versus Diffuse Density for the entire range of the instrument calibration. The values of Instrument Reading should reflect the smallest value (precision) the operator intends to measure. If he w111 read to 0.01 density units, then the table should increment Instrument Reading by that unit. In use, it is a simple matter to look up the Instrument Reading in the 11sting and 1 ts corresponding value of Diffuse Density. There is no problem of IInes to follow, and the contiguous pairing of the two numbers simplifies use. The major problem 1 les in the preparation of the table.

Ordinarily, 22 points are avallable from the calibration (including the point 0,0 ). The remainder of the values, those inbetween the calibration points must be calculated. The calculation of 400 of more points, using any of the various algorlthms provided in classical texts on numerical analysis will be prohibitive in time unless carried out on a digital computer. However, once reduced to a program for the computer, the computation and printing of the table is vastly simplifled, and gives the calibration quickly and efficlently. Futhermore, as the instrument changes 1 ts performance (as $1 t$ "wearsIn"), new calibration tables can be computed and printed with very little additional expenditure of time and effort. Updating the calibration ceases to be a major undertaking.

\section{COMPUTER PROGRAM FOR CALIBRATION TABLES}

A computer program has been prepared for use at NBS by the Optics and Micrometrology Section, for the express purpose of calculating densitometer calibration tables. This program as shown in the listing of the Appendix will handle densities up to 6.0 (with an expansion of 
two arrays, this limit can be extended). The program name 18 DENCAL; a typical print-out 18 shown in the Appendix, following the 11sting.

DENCAL calculates the density values between callbration points through a technique of spline-fitting, a method completely analogous to using a French Curve to smooth points into a continuous curve on a graph. Detalls of general spline-fitting can be found in Ralph $H$. Pennington, Introductory Computer Methods and Numer1cal Analys18, 2d Ed., (The MacM11lan Company, Toronto, Canada, 1970), pp. 445-452. Every calibration point 11 es on the "curve," and 1 t 18 as accurate as any of the standard interpolation formulas.

The program 18 written in BASIC language, and used at NBS through a teletype un1t with a commercial t1me-sharing computer. BASIC, in form and content, is equivalent to elementary FORTRAN and can quickly be converted to that language if a user so requires. The Print and Format statements for setting up the tables have purposely been written with conversion to FORTRAN in mind.

Data Input for DENCAL:

The following procedure should be used for entering data in DENCAL :

1) On line 900, enter the number of palrs of points to be used in the calibration, and which will listed in lines following that entry.

2) Following 11ne 900, enter data in the form of pa1rs of points (palred as INSTRUMENT READING, DIFFUSE DENSITY), 1n Increasing order, Including the lower instrument adjustement end-point, 0,0. See lines 910 and subsequent in the 11sting of the Appendix for a specific example.

3) DENCAL w111 Increment the Instrument Reading column of the table by whatever value the user specif1es. In the c1ted 11sting, it is spectfled as 0.01 , and this should be used for those instruments with a real or implied precision of 0.01 . Enter the desired value on 11ne 920, or do not patch-1n if the one already there 18 correct.

Output from DENCAL:

The program prints two column-palrs per page; the columns contain 50 palrs of values each. Sufficlent spacing is provided in the program's print-outs so that each page can be trimmed to an $8-1 / 2 \times 11$ Inch size for insertion 1nto standard-size notebooks. The input 
(calibration) data are not printed-out in a separate group. However, the actual points can be checked against the table after preparation; the spline-fit procedure will always have the basic calibration points in the table.

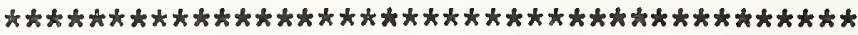

A punched tape containing DENCAL is available from the Optics and Micrometrology Section for loan to those interested in using the program. Direct requests for this tape or for additional information to: R. E. Swing, A-123 Metrology Bullding, National Bureau of Standards, Washington, D. C., 20234. 


\section{APPENDIX}

DENCAL :

A Computer Program for Preparing Densitometer Calibration Tables 

OOI* RICHARD E. SWING, PROGKAM: UEINCAL

$002 *$

003 * THIS PRGgRAM PKEPARES A CALIBKATIUN TABLE THAT KELATES

004 * INSTRUMENT REAUINGS TU A CALIBKATED HHYSICAL STANDAKD.

005 * THE TABLE STEPS INSTRUMENT KEAUING aCCOKUING TO THE VALUE

006 * DN LINE 920. CHAIVGE FORMAT STATEMENTS UN LINES 502.506

007 * 525,528, $541,343,547,560$ ANU 370 AS KEQUIRED FUK THE SHECIFIC

008 * INSTRUMENT, AND PATCH-IN THE ARPKOHKIATE DATA UN LINES

009 * 910 AND SUBSEQUENT. CHANGE UATA LINE 900 TD KEFLECT THE

010 * NUMBER UF PAIRS UF PUINTS. DATA MUST BE LISTED IN INCREAS-

011 * ING OKDER, IN PAIRS, INSTKUMENT KEADING HIKST IN EACH PAIR.

$012 *$

013 DIM $A(30,3), C(4,30)$

014 DIM G(601), H(601)

015 DIM $X(30), Y(30), Z(30), B(30), D(30), E(30), P(39)$

$016 \mathrm{FOR} J=1 \mathrm{TO} 10$

017 PRINT

018 NEXT J

020 GDSUB 540 'PRINT TABLE HEAUING'

024 READ $M$

026 HOR I = I TDM INPUT THE DATA'

027 READ X(I),Y (I)

028 NEXT I

029 READ C

$030 \mathrm{~B}=(X(M)-X(1)) / C$

031 If $A>601$ GH $T B 601$

$032 M 1=M-1$

'CALCULATE HI-C๖EHFICIENTS

$034 \mathrm{FGRK}=1 \mathrm{TO} M 1$

$036 D(K)=x(k+1)-x(k)$

$038 P(K)=D(K) / 6$

$040 E(K)=(Y(K+1)-Y(K)) / D(K)$

042 NEXT $K$

$044 \mathrm{FOR} K=2 \mathrm{TH} M I$

$046 B(K)=E(K)-E(K-1)$

048 NEXT K

$050 A(1,2)=-1 \cdot 0-D(1) / D(2)$

$052 A(1,3)=D(1) / D(2)$

$054 A(2,3)=P(2)-P(1) * A(1,3)$

$056 A(2,2)=2 *(P(1)+P(2))-P(1) * A(1,2)$

$058 A(2,3)=A(2,3) / A(2,2)$

$060 B(2)=B(2) / A(2,2)$

$062 F \cup R K=3 \mathrm{~T} U \mathrm{MI}$

$064 A(K, 2)=2 *(P(K-1)+P(K))-P(K-1) * A(K-1,3)$

$066 B(K)=B(K)-P(K-1) * B(K-1)$

$068 A(K, 3)=P(K) / A(K, 2)$

$070 B(K)=B(K) / A(K, 2)$

072 NEXT K

$074 \theta=D(M-2) / D(M-1)$

$076 A(M, 1)=1+Q+A(M-2,3)$

$078 A(M, 2)=-0-A(M, 1) * A(M-1,3)$

$080 B(M)=B(M-2)-A(M, 1) * B(M-1)$

$082 Z(M)=B(M) / A(M, 2)$

$084 M 2=M-2$

$086 \mathrm{~F} \boxminus R I=1 \mathrm{~TB} M 2$

$088 K=M-I$

$090 Z(K)=B(K)-A(K, 3) * Z(K+1)$

092 NEXT I 


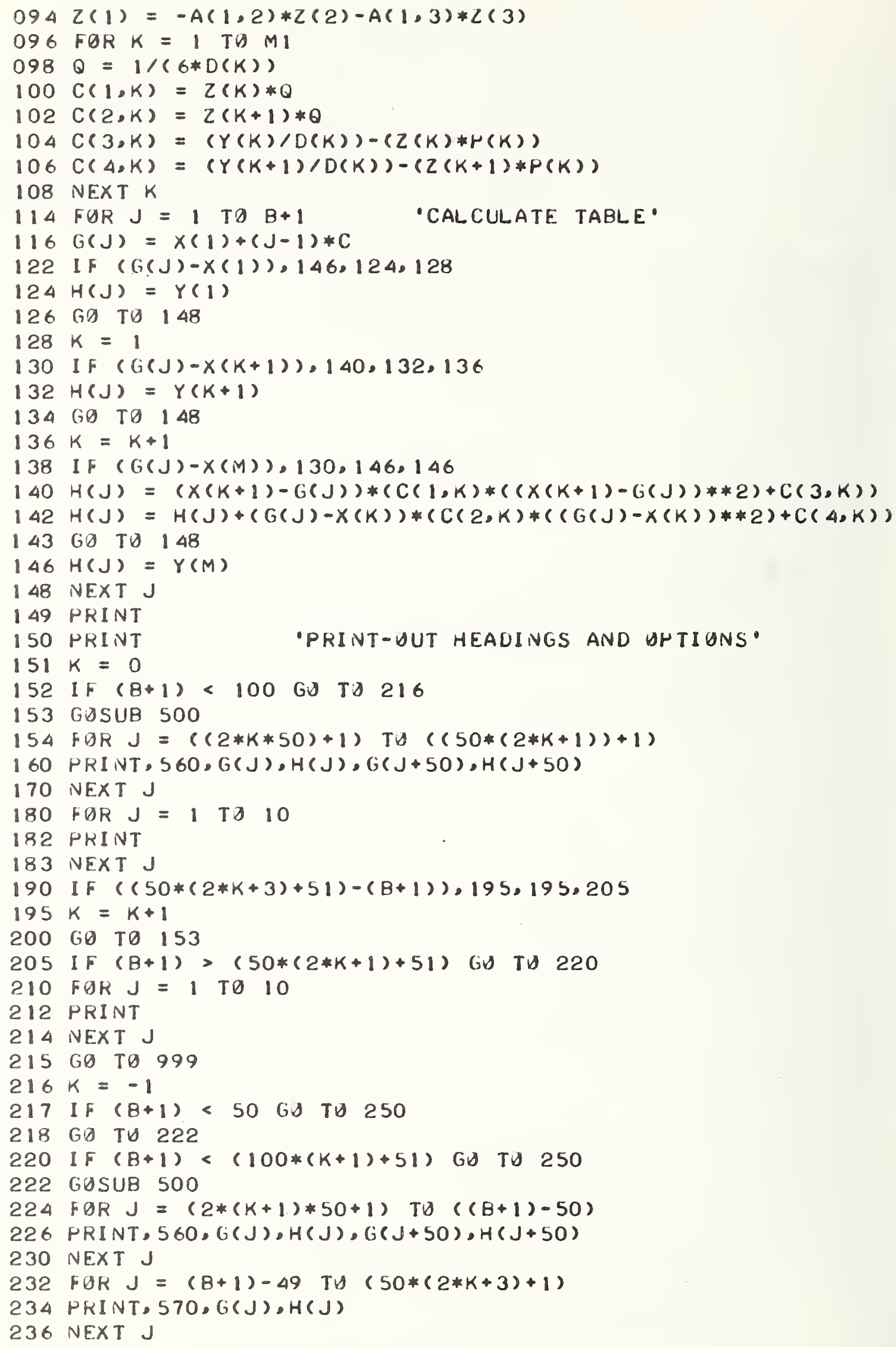


$540 \mathrm{FORJ} J=1 \mathrm{TO} 10$

242 PRINT

244 NEXT J

245 GD TO 999

250 GiUSUB 522

252 *VK J $=(2 *(K+1) * 50+1)$ TU $(B+1)$

254 PRINT, $570, G(J), H(J)$

256 NEXT J

260 FIS $J=1$ TU $(60+2 *(K+1) * 50-8)$ 'EXTKA SHACES, LAST HAGE.

262 PKINT

264 NEXT J

$265 \quad G 0 \mathrm{TU} 999$

500 PRINT, 502 'TWB-COLUMN HEAUING SUBKDUTINE.

SO2 PMT X5, "INSTKUM", X5, "UI P USE", X1 15, "INSTKUM", X S, "OIFFUSE"

SOA PKINT, 506

506 FMT X5, "READING", X5, "DENSITY", XI S, "KEADING", XS, "UENSITY"

508 PKINT

509 RETURIN

S22 PKINT, 525 'SINGLE-CULUMN HEAUING SUBKUUTINE'

S25 FMT X5, "INSTRUM", X 5, "DIF FUSE"

527 PRINT, $S 28$

528 PMT XS, "READING", X5, "DFNSITY"

5 ? PRINT

530 KETUKN

540 PRINT, 541 'TABLE-HEADING SUBRDUTINE'

541 FMT "DENSITBMETFK CALIBRATI BN TABLE"

542 . PRINT, $S 43$

\43 FMT "XYZ CBMPANY LABUKATUKY, INSTKUMENT "7"

545 PRINT "DATE: "'

546 PKINT, 547, TIM( 1), TIM(2), TIM(3)

547 FMT $13, " /,, 13, " / \cdots, 13$

548 PKINT

549 PRINT

550 RETURN

SSS * HORMAT STATEMENTS

560 FMT $\times 3, F 8,2, \times 4, F 8,2, \times 14,18,2, \times 4,18.2$

570 FMT $\times 3, F 8,2, \times 4,18.2$

600 * WARNING STATEMENT ABUUT ARKAY SIZE

601 PKINT "THE CALCULATI DNS WILL KEUUIKE MUKE AKKAY CARACITY."

60? PRINT "INCKEASE THE DIMENSIUNS UF Ge, AND HC,,"

603 HKINT, 604 , INT $(B+1)$

604 FMT "ON LINE 014, TH", I 5, ", ", " AND KUN AGAIN."

606 PRINT

607 Gด TV 999

899 * UATA SECTI UIV

$\rightarrow 00$ DATA 20

910 DATA $0,0,0 \cdot 04,0.035,0.21,0.23,0.42,0.43,0.64,0.64$

912 DATA $0.83,0.84,1.04,1 \cdot 05,1 \cdot 23,1 \cdot 25,1.45,1.45,1.65,1.65$

914 DATA $1.86,1.86,2.04,2 \cdot 05,2 \cdot 22,2 \cdot 25,2 \cdot 43,2 \cdot 465,2 \cdot 65,2.68$

916 DATA $2.86,2.88,3.05,3.045,3.22,3.245$

918 DATA $3.42,3.365,3.64,3.68$

920 DATA 0.01

999 END 
DENSITHMETER CALIBRATIDN TABLE

XYZ COMPANY LABURATURY, INSTRUMENT 7

\begin{tabular}{|c|c|c|c|}
\hline INSTRUM & DI FFUSE & INSTRUM & $\begin{array}{l}\text { DIFFUSE } \\
\text { DENSITY }\end{array}$ \\
\hline & DENSITY & READING & \\
\hline .00 & .00 & .50 & $\cdot 50$ \\
\hline .01 & .01 & .31 & .51 \\
\hline .02 & .03 & . 32 & . 52 \\
\hline .03 & .04 & - \3 & .53 \\
\hline .04 & .05 & .54 & .54 \\
\hline .05 & .07 & .55 & .55 \\
\hline .06 & .08 & .56 & .56 \\
\hline .07 & .09 & • \7 & .57 \\
\hline .08 & .10 & • S8 & - 58 \\
\hline .09 & .11 & • ל & . 59 \\
\hline .10 & .12 & .60 & .60 \\
\hline .11 & .13 & .61 & .61 \\
\hline .12 & .14 & .62 & .62 \\
\hline .13 & - Ib & .63 & .63 \\
\hline .14 & .16 & .64 & .64 \\
\hline .15 & .17 & .65 & .65 \\
\hline .16 & .18 & .66 & .66 \\
\hline .17 & .19 & .67 & .67 \\
\hline .18 & $\cdot 20$ & - 68 & - 68 \\
\hline .19 & $\cdot 21$ & .69 & .69 \\
\hline$\cdot 20$ & $\cdot 22$ & .70 & .70 \\
\hline .21 & .23 & .71 & .71 \\
\hline . 22 & .24 & .72 & .72 \\
\hline .23 & .25 & .73 & .73 \\
\hline .24 & .26 & .74 & .75 \\
\hline .25 & $\cdot 27$ & .75 & .76 \\
\hline .26 & .28 & .76 & .77 \\
\hline .27 & .29 & .77 & $\cdot 78$ \\
\hline . 28 & .30 & .78 & .79 \\
\hline .29 & .31 & . 79 & .80 \\
\hline . 30 & .32 & .80 & .81 \\
\hline .31 & .32 & .81 & .82 \\
\hline .32 & .33 & .82 & .83 \\
\hline .33 & .34 & .83 & .84 \\
\hline .34 & .35 & .84 & .85 \\
\hline .35 & .36 & .85 & .86 \\
\hline .36 & .37 & .86 & .87 \\
\hline .37 & $\cdot 38$ & .87 & .88 \\
\hline . 38 & .39 & .88 & .89 \\
\hline . 39 & .40 & .89 & .90 \\
\hline .40 & .41 & .90 & .91 \\
\hline .41 & - 42 & .91 & .92 \\
\hline .42 & .43 & .92 & .93 \\
\hline .43 & .44 & .93 & .94 \\
\hline .44 & .45 & .94 & .95 \\
\hline .45 & .46 & .95 & .96 \\
\hline .46 & .47 & .96 & .97 \\
\hline .47 & .48 & .97 & .98 \\
\hline .48 & .49 & .98 & .99 \\
\hline .49 & .50 & .99 & 1.00 \\
\hline .50 & .50 & 1.00 & 1.01 \\
\hline
\end{tabular}




\begin{tabular}{|c|c|c|c|}
\hline $\begin{array}{l}\text { INSTRUM } \\
\text { KEAUING }\end{array}$ & $\begin{array}{l}\text { OI FFUSE } \\
\text { DENSITY }\end{array}$ & $\begin{array}{l}\text { INSTKUM } \\
\text { KEADINYG }\end{array}$ & $\begin{array}{l}\text { DIFFUSE } \\
\text { DENSITY }\end{array}$ \\
\hline 1.00 & 1.01 & 1.50 & $1 \cdot 50$ \\
\hline 1.01 & 1.02 & $1 \cdot 51$ & $1 \cdot 51$ \\
\hline $1 \cdot 02$ & 1.03 & 1.52 & $1 \cdot 52$ \\
\hline 1.03 & 1.04 & $1 \cdot 53$ & $1 \cdot 53$ \\
\hline 1.04 & 1.05 & 1.54 & 1.54 \\
\hline 1.05 & 1.06 & 1.55 & 1.55 \\
\hline 1.06 & 1.07 & 1.56 & 1.56 \\
\hline 1.07 & 1.08 & 1.57 & 1.57 \\
\hline 1.08 & 1.09 & $1 \cdot 58$ & $1 \cdot 58$ \\
\hline 1.09 & $1 \cdot 10$ & $1 \cdot 59$ & $1 \cdot 59$ \\
\hline $1 \cdot 10$ & $1 \cdot 11$ & $1 \cdot 60$ & $1 \cdot 60$ \\
\hline $1 \cdot 11$ & $1 \cdot 12$ & 1.61 & 1.61 \\
\hline $1 \cdot 12$ & $1 \cdot 14$ & 1.62 & $1 \cdot 62$ \\
\hline $1 \cdot 13$ & 1.15 & $1 \cdot 63$ & $1 \cdot 63$ \\
\hline $1 \cdot 14$ & $1 \cdot 16$ & 1.64 & 1.64 \\
\hline 1.15 & $1 \cdot 17$ & 1.65 & 1.65 \\
\hline $1 \cdot 16$ & $1 \cdot 18$ & 1.66 & 1.66 \\
\hline 1.17 & $1 \cdot 19$ & 1.67 & 1.67 \\
\hline $1 \cdot 18$ & $1 \cdot 20$ & $1 \cdot 68$ & $1 \cdot 68$ \\
\hline $1 \cdot 19$ & $1 \cdot 21$ & 1.69 & $1 \cdot 69$ \\
\hline $1 \cdot 20$ & 1.22 & $1 \cdot 70$ & $1 \cdot 70$ \\
\hline $1 \cdot 21$ & $1 \cdot 23$ & 1.71 & 1.71 \\
\hline $1 \cdot 22$ & 1.24 & 1.72 & 1.72 \\
\hline $1 \cdot 23$ & 1.25 & 1.73 & 1.73 \\
\hline $1 \cdot 24$ & $1 \cdot 26$ & 1.74 & 1.74 \\
\hline 1.25 & $1 \cdot 27$ & 1.75 & 1.75 \\
\hline $1 \cdot 26$ & $1 \cdot 28$ & 1.76 & 1.76 \\
\hline $1 \cdot 27$ & $1 \cdot 29$ & 1.77 & 1.77 \\
\hline $1 \cdot 28$ & $1 \cdot 30$ & 1.78 & 1.78 \\
\hline $1 \cdot 29$ & $1 \cdot 31$ & 1.79 & 1.79 \\
\hline $1 \cdot 30$ & $1 \cdot 32$ & $1 \cdot 80$ & 1.80 \\
\hline $1 \cdot 31$ & $1 \cdot 32$ & 1.81 & 1.81 \\
\hline $1 \cdot 32$ & $1 \cdot 33$ & 1.82 & $1 \cdot 82$ \\
\hline $1 \cdot 33$ & 1.34 & 1.83 & 1.83 \\
\hline $1 \cdot 34$ & $1 \cdot 35$ & 1.84 & 1.84 \\
\hline $1 \cdot 35$ & $1 \cdot 36$ & 1.85 & 1.85 \\
\hline $1 \cdot 36$ & $1 \cdot 37$ & 1.86 & 1.86 \\
\hline $1 \cdot 37$ & $1 \cdot 38$ & 1.87 & 1.87 \\
\hline $1 \cdot 38$ & $1 \cdot 39$ & $1 \cdot 88$ & $1 \cdot 88$ \\
\hline 1.39 & $1 \cdot 40$ & $1 \cdot 89$ & $1 \cdot 89$ \\
\hline $1 \cdot 40$ & $1 \cdot 40$ & 1.90 & 1.90 \\
\hline $1 \cdot 41$ & $1 \cdot 41$ & 1.91 & 1.91 \\
\hline $1 \cdot 42$ & $1 \cdot 42$ & 1.92 & 1.92 \\
\hline 1.43 & $1 \cdot 43$ & 1.93 & 1.93 \\
\hline 1.44 & 1.44 & 1.94 & 1.94 \\
\hline 1.45 & 1.45 & 1.95 & 1.95 \\
\hline 1.46 & 1.46 & 1.96 & 1.96 \\
\hline $1 \cdot 47$ & 1.47 & 1.97 & 1.97 \\
\hline $1 \cdot 48$ & $1 \cdot 48$ & 1.98 & 1.98 \\
\hline $1 \cdot 49$ & $1 \cdot 49$ & 1.99 & 2.00 \\
\hline $1 \cdot 50$ & $1 \cdot 50$ & $2 \cdot 00$ & $2 \cdot 01$ \\
\hline
\end{tabular}




\begin{tabular}{|c|c|c|c|}
\hline $\begin{array}{l}\text { INSTRUM } \\
\text { READING }\end{array}$ & $\begin{array}{l}\text { DI F FUSE } \\
\text { DENSITY }\end{array}$ & $\begin{array}{l}\text { INSTKUM } \\
\text { READING }\end{array}$ & $\begin{array}{l}\text { DIFFUSE } \\
\text { DENSITY }\end{array}$ \\
\hline $2 \cdot 00$ & 2.01 & $2 \cdot 50$ & $2 \cdot 53$ \\
\hline 2.01 & 2.02 & 2.51 & 2.54 \\
\hline $2 \cdot 02$ & 2.03 & $2 \cdot 52$ & $2 \cdot 55$ \\
\hline 2.03 & 2.04 & 2.53 & 2.56 \\
\hline 2.04 & 2.05 & $2 \cdot 54$ & $2 \cdot 57$ \\
\hline 2.05 & 2.06 & 2.55 & $2 \cdot 58$ \\
\hline 2.06 & $2 \cdot 07$ & $2 \cdot 56$ & $2 \cdot 59$ \\
\hline $2 \cdot 07$ & 2.08 & $2 \cdot 57$ & $2 \cdot 60$ \\
\hline $2 \cdot 08$ & 2.09 & $2 \cdot 58$ & $2 \cdot 61$ \\
\hline 2.09 & $2 \cdot 11$ & $2 \cdot 59$ & $2 \cdot 62$ \\
\hline $2 \cdot 10$ & $2 \cdot 12$ & $2 \cdot 60$ & $2 \cdot 63$ \\
\hline $2 \cdot 11$ & $2 \cdot 13$ & 2.61 & 2.64 \\
\hline $2 \cdot 12$ & $2 \cdot 14$ & $2 \cdot 62$ & $2 \cdot 65$ \\
\hline $2 \cdot 13$ & $2 \cdot 15$ & 2.63 & $2 \cdot 66$ \\
\hline 2.14 & $2 \cdot 16$ & 2.64 & $2 \cdot 67$ \\
\hline $2 \cdot 15$ & $2 \cdot 17$ & 2.65 & $2 \cdot 68$ \\
\hline 2.16 & $2 \cdot 18$ & $2 \cdot 66$ & $2 \cdot 69$ \\
\hline $2 \cdot 17$ & $2 \cdot 20$ & $2 \cdot 67$ & $2 \cdot 70$ \\
\hline $2 \cdot 18$ & $2 \cdot 21$ & $2 \cdot 68$ & 2.71 \\
\hline $2 \cdot 19$ & $2 \cdot 22$ & $2 \cdot 69$ & $2 \cdot 72$ \\
\hline $2 \cdot 20$ & $2 \cdot 23$ & $2 \cdot 70$ & 2.73 \\
\hline $2 \cdot 21$ & $2 \cdot 24$ & 2.71 & 2.74 \\
\hline $2 \cdot 22$ & $2 \cdot 25$ & $2 \cdot 72$ & 2.75 \\
\hline $2 \cdot 23$ & $2 \cdot 2.6$ & $2 \cdot 73$ & 2.76 \\
\hline $2 \cdot 24$ & $2 \cdot 27$ & 2.74 & 2.77 \\
\hline $2 \cdot 25$ & $2 \cdot 28$ & $2 \cdot 75$ & $2 \cdot 78$ \\
\hline $2 \cdot 26$ & $2 \cdot 29$ & $2 \cdot 76$ & $2 \cdot 79$ \\
\hline $2 \cdot 27$ & $2 \cdot 30$ & $2 \cdot 77$ & $2 \cdot 80$ \\
\hline $2 \cdot 28$ & 2.31 & $2 \cdot 78$ & 2.81 \\
\hline $2 \cdot 29$ & $2 \cdot 32$ & $2 \cdot 79$ & $2 \cdot 82$ \\
\hline $2 \cdot 30$ & $2 \cdot 33$ & $2 \cdot 80$ & 2.83 \\
\hline 2.31 & $2 \cdot 34$ & 2.81 & 2.84 \\
\hline $2 \cdot 32$ & $2 \cdot 36$ & $2 \cdot 82$ & 2.85 \\
\hline $2 \cdot 33$ & $2 \cdot 37$ & 2.83 & $2 \cdot 85$ \\
\hline $2 \cdot 34$ & $2 \cdot 38$ & $2 \cdot 84$ & 2.86 \\
\hline $2 \cdot 35$ & $2 \cdot 39$ & 2.85 & 2.87 \\
\hline $2 \cdot 36$ & $2 \cdot 40$ & 2.86 & $2 \cdot 88$ \\
\hline $2 \cdot 37$ & $2 \cdot 41$ & $2 \cdot 87$ & $2 \cdot 89$ \\
\hline $2 \cdot 38$ & $2 \cdot 42$ & $2 \cdot 88$ & 2.90 \\
\hline $2 \cdot 39$ & $2 \cdot 43$ & $2 \cdot 89$ & $2 \cdot 90$ \\
\hline $2 \cdot 40$ & $2 \cdot 44$ & 2.90 & 2.91 \\
\hline 2. 41 & $2 \cdot 45$ & 2.91 & 2.92 \\
\hline $2 \cdot 42$ & $2 \cdot 46$ & $2 \cdot 92$ & 2.93 \\
\hline $2 \cdot 43$ & $2 \cdot 47$ & 2.93 & 2.94 \\
\hline $2 \cdot 44$ & $2 \cdot 47$ & 2.94 & 2.94 \\
\hline 2.45 & $2 \cdot 48$ & 2.95 & 2.95 \\
\hline $2 \cdot 46$ & $2 \cdot 49$ & 2.96 & 2.96 \\
\hline $2 \cdot 47$ & $2 \cdot 50$ & 2.97 & 2.97 \\
\hline $2 \cdot 48$ & $2 \cdot 51$ & $2 \cdot 98$ & $2 \cdot 98$ \\
\hline$? \cdot 49$ & $2 \cdot 52$ & 2.99 & 2.99 \\
\hline $2 \cdot 50$ & 2.53 & 3.00 & $2 \cdot 99$ \\
\hline
\end{tabular}




\begin{tabular}{|c|c|}
\hline $\begin{array}{l}\text { INSTRUM } \\
\text { READI ING }\end{array}$ & $\begin{array}{l}\text { DIFFUSE } \\
\text { DENSITY }\end{array}$ \\
\hline $3: 00$ & 2.99 \\
\hline 3.01 & 3.00 \\
\hline 3.02 & 3.01 \\
\hline 3.03 & 3.02 \\
\hline 3.04 & 3.03 \\
\hline 3.05 & 3.04 \\
\hline 3.06 & 3.06 \\
\hline 3.07 & 3.07 \\
\hline 3.08 & 3.08 \\
\hline 3.09 & 3.09 \\
\hline $3 \cdot 10$ & $3 \cdot 10$ \\
\hline 3.11 & $3 \cdot 12$ \\
\hline $3 \cdot 12$ & 3.13 \\
\hline $3 \cdot 13$ & $3 \cdot 14$ \\
\hline $3 \cdot 14$ & $3 \cdot 16$ \\
\hline $3 \cdot 15$ & $3 \cdot 17$ \\
\hline $3 \cdot 16$ & $3 \cdot 18$ \\
\hline 3.17 & $3 \cdot 19$ \\
\hline $3 \cdot 18$ & $3 \cdot 20$ \\
\hline $3 \cdot 19$ & $3 \cdot 21$ \\
\hline $3 \cdot 20$ & $3 \cdot 23$ \\
\hline $3 \cdot 21$ & $3 \cdot 24$ \\
\hline 3.?? & $3 \cdot 24$ \\
\hline 3.23 & 3.25 \\
\hline $3 \cdot 24$ & 3.26 \\
\hline 3.25 & 3.2 .7 \\
\hline $3 \cdot 26$ & $3 \cdot 28$ \\
\hline 3.27 & 3.28 \\
\hline $3 \cdot 28$ & $3 \cdot 29$ \\
\hline $3 \cdot 27$ & $3 \cdot 30$ \\
\hline $3 \cdot 30$ & $3 \cdot 30$ \\
\hline $3 \cdot 31$ & $3 \cdot 31$ \\
\hline $3 \cdot 32$ & $3 \cdot 31$ \\
\hline 3.33 & $3 \cdot 32$ \\
\hline 3.34 & $3 \cdot 32$ \\
\hline $3 \cdot 35$ & $3 \cdot 33$ \\
\hline $3 \cdot 36$ & $3 \cdot 33$ \\
\hline $3 \cdot 37$ & $3 \cdot 34$ \\
\hline $3 \cdot 38$ & $3 \cdot 34$ \\
\hline $3 \cdot 39$ & 3.35 \\
\hline $3 \cdot 40$ & $3 \cdot 35$ \\
\hline $3 \cdot 41$ & $3 \cdot 36$ \\
\hline $3 \cdot 42$ & $3 \cdot 36$ \\
\hline 3.43 & $3 \cdot 37$ \\
\hline 3.44 & $3 \cdot 38$ \\
\hline 3.45 & $3 \cdot 39$ \\
\hline $3 \cdot 46$ & $3 \cdot 39$ \\
\hline 3.47 & 3.40 \\
\hline $3 \cdot 49$ & 3.41 \\
\hline 3.49 & $3 \cdot 42$ \\
\hline $3 \cdot 50$ & $3 \cdot 43$ \\
\hline
\end{tabular}

$\begin{array}{ll}\text { INSTKUM } & \text { DIFFUSE } \\ \text { KEADING } & \text { DENSITY }\end{array}$

$3.50 \quad 3.43$

$3.51 \quad 3.44$

$3.52 \quad 3.45$

$3.53 \quad 3.47$

$3.54 \quad 3.48$

$3.55 \quad 3.49$

$3.56 \quad 3.51$

$3.57 \quad 3.53$

$3.58 \quad 3.55$

$3.59 \quad 3.56$

$3.60 \quad 3.58$

$3.61 \quad 3.61$

$3.62 \quad 3.63$

$3.63 \quad 3.65$

$3.64 \quad 3.68$ 
NBS. 114A (REV.7-73)

\begin{tabular}{|c|c|c|}
\hline $\begin{array}{l}\text { U.S. DEPT. OF COMM. } \\
\text { BIBLIOGRAPHIC DATA } \\
\text { SHEET }\end{array}$ & $\begin{array}{l}\text { 1. HIBI.I A IION (OR RI:PORT NO. } \\
\text { NBSIR 75-682 }\end{array}$ & 3. Recipient's Accession No. \\
\hline \multirow{2}{*}{\multicolumn{2}{|c|}{$\begin{array}{l}\text { 4. TITLL: AND SIITTTI: } \\
\text { BASIC CONSIDERATIONS OF DEHSITONETER ADUUSTMENT AND } \\
\text { CALIBRATION }\end{array}$}} & $\begin{array}{l}\text { 5. Publication Date } \\
\text { February } 1975\end{array}$ \\
\hline & & 6. Performing Organization Code \\
\hline \multicolumn{2}{|l|}{ 7. AUIIOR(S) } & 8. Performing Organ. Report No. \\
\hline \multicolumn{2}{|c|}{$\begin{array}{l}\text { 9. PIERFORMING, (ORGANIZATION NAME ANI) ADI)RESS } \\
\text { NATIONAL BUREAU OF STANDARDS } \\
\text { OEPARTMENT OF COMMERCE } \\
\text { WASHINGTON, D.C. } 20234\end{array}$} & $\begin{array}{l}\text { 10. Propect/Task/Work Unit No. } \\
2320187 \\
\text { 11. Contract/Grant No. }\end{array}$ \\
\hline \multicolumn{3}{|c|}{$\begin{array}{l}\text { 12. Sponsoring Organization Name and (umplete Addres (Street, City, State, ZIP) } \\
\text { Same as No. } 9\end{array}$} \\
\hline 5. SUPPI.I:MLNTARY NOTI & NBS Report 10 & \\
\hline
\end{tabular}

16. ABSTRAC I' (A 200-word or less factual summary of most stmificant information. If document includes a significant bibliography or literature survey, mention it here.)

The adjustment and calibration of a densitoneter are considered. This 18 accomplished through the use of physical masurement standards wth a procedure appropriate for the 1netrunent, and brings the instrument reeponse in $11 n e$ with measurements traceable to NBS. The difference between primary and secondary physical measurement standards for diffuse (visual) density is discussed. A callbration table 18 suggested for best use of the Instrument and a computer program (BASIC languege) 1a provided that will calculate and print a table relating instrument reading to diffuse (visual) density.

17. KEY WORDS (six to twelve entries; alphabetical order; capitalize only the first letter of the first key word unless a proper name; separated by semicolons)

Cal1bration; Callbration table; densitometer; Denaltometry;

Opt1cal density; Optical density standard

18. AVAILABIIITY $\mathbf{x}$ Unlimiced

For Official Distribution. 1)o Not Release eo NTIS

Order From Sup. of Doc., U.S. Government Printing Office

Washington, D.C. 20402, SD Cat. No. C I3

X Order lirom National Technical Information Service (NTIS) Springfield, Virginia 22151

\begin{tabular}{|c|c|}
\hline $\begin{array}{l}\text { 19. SECINRITY CLASS } \\
\text { (THLS REPURT) } \\
\text { UNC ASSHFIED }\end{array}$ & $\begin{array}{l}\text { 21. NO. OF PAGES } \\
18\end{array}$ \\
\hline $\begin{array}{l}\text { 20. SIE(URITY (LAASS } \\
\text { (THIS PAGE) } \\
\text { UN( L.ASSIIIED }\end{array}$ & $\begin{array}{l}\text { 22. Price } \\
\$ 3.25\end{array}$ \\
\hline
\end{tabular}

